\title{
Commentary: Phage Therapy of Staphylococcal Chronic Osteomyelitis in Experimental Animal Model
}

\author{
Stephen T. Abedon * \\ Department of Microbiology, The Ohio State University, Mansfield, Ohio, USA
}

Keywords: phage therapy, chronic infection, antibacterial agents, bacteriophages, staphylococcal infections, animal models

\section{A commentary on}

Phage Therapy of Staphylococcal Chronic Osteomyelitis in Experimental Animal Model by Kishor, C., Mishra, R. R., Saraf, S. K., Kumar, M., Srivastav, A. K., and Nath, G. (2016). Indian J. Med. Res. 143, 87-94. doi: 10.4103/0971-5916.178615

OPEN ACCESS

Edited by:

Joshua D. Nosanchuk, Albert Einstein College of Medicine,

USA

Reviewed by:

Philippe Georgel,

University of Strasbourg, France

Victor Krylov,

I. I. Mechikov Institute for Vaccines and Sera, Russia

*Correspondence: Stephen T. Abedon abedon.1@osu.edu

Specialty section: This article was submitted to Antimicrobials, Resistance and Chemotherapy,

a section of the journal

Frontiers in Microbiology

Received: 20 June 2016

Accepted: 28 July 2016

Published: 10 August 2016

Citation:

Abedon ST (2016) Commentary:

Phage Therapy of Staphylococcal

Chronic Osteomyelitis in Experimental

Animal Model.

Front. Microbiol. 7:1251.

doi: 10.3389/fmicb.2016.01251
Phage therapy - the use of bacterial viruses as equivalents of antibacterial "drugs" - has been practiced for nearly 100 years. Much, particularly since the 1940s, has taken place in the former Soviet Union. Nevertheless, interest in phage therapy in Western countries has been steadily building since the 1980s. Much of this interest has been in response to growing concerns over antibiotic resistance, though there are concerns, as well, over antibiotic side effects (Langdon et al., 2016). Phage therapy in many cases has been used as a means of treating chronic bacterial infections which may be tolerant to antibiotic treatment rather than necessarily also genetically resistant. This antibiotic tolerance is thought to occur predominantly as a consequence of bacterial growth within biofilms (Olsen, 2015). In practice, however, what is going on is that phage therapy has been used to treat bacterial infections against which antibiotics, often following months or years of treatment, have not been successful (e.g., Rhoads et al., 2009; Wright et al., 2009; Miedzybrodzki et al., 2012).

Despite this clinical aspect of phage therapy, pre-clinical studies have not tended to focus experimentally on chronic bacterial infections. There have been exceptions, however, particularly in which a fair amount of time has elapsed between bacterial challenge and start of phage treatment (Table 1). Here I focus on the recent study of Kishor et al. (2016), which employs the longest delay of which I am aware, in an animal model, between bacterial challenge and phage application.

Kishor et al. (2016) present a rabbit model of chronic osteomyelitis caused by a methicillin-resistant isolate of Staphylococcus aureus. Two rabbits were used to test phage cocktail safety (intraperitoneal delivery of $\sim 10^{11}$ plaque-forming units), four served as untreated controls, 12 were treated with phages after $\sim 3$ weeks, and another four were treated with phages after 6 weeks. Cocktails consisted of seven phages and a total of four doses were applied, 2 days between each. Wounds were prepared thusly (p. 89): “ . . a $2 \mathrm{~cm}$ long incision was made at the lateral aspect of distal end of femur and metaphysial area was exposed. With the help of a hand drill, a $5 \mathrm{~mm}$ diameter unicortical defect was created..." Following bacterial inoculation, "The incised area was covered by sterile bandages with one stitch at middle of open area." Phage treatment by injection into the infected area, with either 3- and 6-week delays, resulted in negative cultures in 15 cases. The $16^{\text {th }}$ was sacrificed for study prior to completion of phage administration.

I have a few minor criticisms of the study, which the authors note is "preliminary." First, it is difficult to tell just how many bacteria were applied. Second, all control rabbits were sacrificed during week 6, meaning that there were no no-treatment controls for the 6-week-delay experiments. Lastly is the notion of "lysis of bacteria from outside," which I interpret as reference 
TABLE 1 | Animal models of human phage therapy with treatment delays exceeding $24 \mathrm{~h}^{\mathrm{a}}$

\begin{tabular}{|c|c|c|c|c|c|c|}
\hline $\begin{array}{l}\text { Organism(s) } \\
\text { treated }\end{array}$ & $\begin{array}{l}\text { Delay } \\
\text { before } \\
\text { treatment }^{b}\end{array}$ & Challenge & Consequence & Treatment & Results $^{c}$ & References \\
\hline Escherichia coli & $168 \mathrm{~h}$ & $\begin{array}{l}\text { Force-fed axenic mice } \\
\text { with } 5 \times 10^{7} \mathrm{CFU}\end{array}$ & $\begin{array}{l}\text { Intestinal } \\
\text { colonization }\end{array}$ & $\begin{array}{l}10^{5} \mathrm{PFU} / \mathrm{ml} \text { in drinking } \\
\text { water }\end{array}$ & $\begin{array}{l}\sim 10^{8} \mathrm{CFU} / \mathrm{ml} \text { reduced to } \\
\sim 10^{4} \mathrm{CFU} / \mathrm{ml} \text { in feces }\end{array}$ & $\begin{array}{l}\text { Chibani-Chennoufi } \\
\text { et al., } 2004\end{array}$ \\
\hline $\begin{array}{l}\text { Escherichia coli } \\
\text { 0157:H7 }\end{array}$ & $48 \mathrm{~h}$ & $\begin{array}{l}\text { Force-fed mice with } \\
10^{9} \mathrm{CFU}\end{array}$ & $\begin{array}{l}\text { Intestinal } \\
\text { colonization }\end{array}$ & $\begin{array}{l}\text { Force fed } 10^{8} \mathrm{PFU}, 1 \\
\text { dose, or } 10^{10} \mathrm{PFU}, 1 \\
\text { dose or "daily" }\end{array}$ & $\begin{array}{l}<10^{3} \text { vs. }<10^{2} \text { CFU/g in } \\
\text { feces for control (etc.) vs. } \\
\text { "daily" treatment, around } \\
\text { day } 8\end{array}$ & Tanji et al., 2005 \\
\hline $\begin{array}{l}\text { Mycobacterium } \\
\text { avium }\end{array}$ & $168 \mathrm{~h}$ & IV $3 \times 10^{7}$ CFU to mice & $\begin{array}{l}\text { Continuing } \\
\text { replication }\end{array}$ & $\begin{array}{l}\text { IV } 8 \times 10^{9} \text { PFU or } 4 \times \\
10^{7} \text { phage-infected } M \text {. } \\
\text { smegmatis in } 100 \mu \text { I, } 1 \\
\text { or } 2 \text { doses }\end{array}$ & $\begin{array}{l}\sim 0.5 \text {-log fewer CFU in } \\
\text { spleen for phage-infected } \\
\text { M. smegmatis, day } 14, \text { no } \\
\text { reduction for phage only }\end{array}$ & $\begin{array}{l}\text { Danelishvili et al., } \\
2006\end{array}$ \\
\hline $\begin{array}{l}\text { Staphylococcus } \\
\text { aureus }\end{array}$ & $96 \mathrm{~h}$ & $\begin{array}{l}\text { Subcutaneous } 10^{8} \text { or } \\
10^{9} \mathrm{CFU} / \text { mouse }\end{array}$ & $\begin{array}{l}\text { Abscess } \\
\text { development }\end{array}$ & $\begin{array}{l}\text { Subcutaneous } 10^{9} \\
\text { PFU }^{d} \text { in } 200 \mu l, 1 \text { or } 4 \\
\text { doses }\end{array}$ & $\begin{array}{l}\sim 10^{8} \text { vs. } \sim 10^{6} \text { or } \sim 10^{4} \\
\text { CFU per abscess for control } \\
\text { vs. treatments }\end{array}$ & $\begin{array}{l}\text { Capparelli et al., } \\
2007\end{array}$ \\
\hline $\begin{array}{l}\text { Staphylococcus } \\
\text { aureus }\end{array}$ & $240 h$ & IV $5 \times 10^{6} \mathrm{CFU}$ to mice & $\begin{array}{l}\text { Non-lethal } \\
\text { systemic infection }\end{array}$ & $10^{9} \mathrm{PFU}$ in $200 \mu \mathrm{l}^{\mathrm{e}}$ & $\begin{array}{l}\sim 10^{4} \text { CFU vs. } 0 \text { in various } \\
\text { organs, day } 20\end{array}$ & $\begin{array}{l}\text { Capparelli et al., } \\
2007\end{array}$ \\
\hline $\begin{array}{l}\text { Pseudomonas } \\
\text { aeruginosa }\end{array}$ & $96,240 h^{f}$ & $\begin{array}{l}10^{8} \mathrm{CFU} / \mathrm{ml} \text { in mouse } \\
\text { drinking waterg }\end{array}$ & $\begin{array}{l}\text { Gut-derived } \\
\text { septicemia }\end{array}$ & $\begin{array}{l}10^{10} \text { PFU in } 100 \mu \mathrm{l} \\
\text { orally administered }\end{array}$ & $\begin{array}{l}0,10 \text {, and } 66.7 \% 20 \text {-day } \\
\text { survival for no, } 240 \text {, and } \\
96 \text {-h treatments }\end{array}$ & $\begin{array}{l}\text { Watanabe et al., } \\
2007\end{array}$ \\
\hline $\begin{array}{l}\text { Salmonella } \\
\text { enterica }\end{array}$ & $48,336 h$ & $\begin{array}{l}\text { IV } 10^{6} \text { or } 10^{5} \mathrm{CFU} \text {, } \\
\text { respectively, to mice }\end{array}$ & $\begin{array}{l}\text { Sublethal systemic } \\
\text { infection }\end{array}$ & IV $10^{7} \mathrm{PFU}$ in $100 \mu \mathrm{I}$ & $\begin{array}{l}\sim 10^{4} \mathrm{CFU} \text { reduced to } 0 \text { in } \\
\text { various organs }\end{array}$ & $\begin{array}{l}\text { Capparelli et al., } \\
2010\end{array}$ \\
\hline $\begin{array}{l}\text { Acinetobacter } \\
\text { baumannii, } \\
\text { Pseudomonas } \\
\text { aeruginosa, } \\
\text { Staphylococcus } \\
\text { aureus }\end{array}$ & $96 \mathrm{~h}$ & $\begin{array}{l}\text { Mouse wounds } \\
\text { injected with } 100 \mu \text { l of } \\
\text { organisms of one type }\end{array}$ & $\begin{array}{l}\text { Infected wound } \\
\text { (diabetes mellitus } \\
\text { model) }\end{array}$ & $\begin{array}{l}10^{8}-10^{9} \text { PFU } \\
\text { presumably topical } \\
\text { following one or more } \\
\text { debridements, }>10 \\
\text { doses }\end{array}$ & $\begin{array}{l}\sim 10^{5} \text { vs. } \sim 10^{2} \text { CFU/swab, } \\
\text { day } 8, \text { control vs. treatment } \\
(\text { S. aureus })^{\mathrm{h}}\end{array}$ & Mendes et al., 2013 \\
\hline $\begin{array}{l}\text { Mycobacterium } \\
\text { ulcerans }\end{array}$ & $792 h$ & $\begin{array}{l}\text { Subcutaneous } 3 \times 10^{5} \\
\text { CFU into mouse } \\
\text { footpad }\end{array}$ & $\begin{array}{l}\text { Footpad swelling } \\
\text { with continuing } \\
\text { replication }\end{array}$ & $\begin{array}{l}\text { Subcutaneous } 10^{8} \\
\text { PFU into mouse } \\
\text { footpad }\end{array}$ & $\begin{array}{l}\sim 3 \times 10^{5} \text { vs. } \sim 3 \times 10^{3} \\
\text { CFU/footpad, day } 68 \\
\text { control vs. treatment }\end{array}$ & Trigo et al., 2013 \\
\hline $\begin{array}{l}\text { Staphylococcus } \\
\text { aureus (MRSA) }\end{array}$ & $96 \mathrm{~h}$ & $\begin{array}{l}\text { Intranasal } 10^{6} \\
\text { CFU/mouse }\end{array}$ & $\begin{array}{l}\text { Nare potentially } \\
\text { transient } \\
\text { colonization }\end{array}$ & $\begin{array}{l}\text { Intranasal } 50 \mu \text { l of } 10^{7} \\
\text { PFU/ml, } 2 \text { doses }\end{array}$ & $\begin{array}{l}\sim 10^{5.5} \text { vs. } \sim 10^{1} \mathrm{CFU} / \mathrm{g}, \\
\text { day } 11, \text { control vs. } \\
\text { treatment }\end{array}$ & $\begin{array}{l}\text { Chhibber et al., } \\
2014\end{array}$ \\
\hline $\begin{array}{l}\text { Staphylococcus } \\
\text { aureus }\end{array}$ & $168 h$ & $\begin{array}{l}\text { Sinus inoculation of } \\
\text { sheep }\end{array}$ & Sinusitis model & $\begin{array}{l}\text { Sinus inoculation of } \\
100 \mathrm{ml} \text { of } 2 \times 10^{8} \\
\text { PFU/ml, } 5 \text { doses }\end{array}$ & $\begin{array}{l}\sim 80 \% \text { reduction in biofilm } \\
\text { biomass, control vs. } \\
\text { treatment }\end{array}$ & Drilling et al., 2014 \\
\hline $\begin{array}{l}\text { Acinetobacter } \\
\text { baumannii } \\
\text { (multi-drug } \\
\text { resistant) }\end{array}$ & $48 h$ & $\begin{array}{l}10^{8} \mathrm{CFU} \text { inoculated } \\
\text { into wound of diabetic } \\
\text { rats }\end{array}$ & $\begin{array}{l}\text { Abscess } \\
\text { development }\end{array}$ & $\begin{array}{l}400 \mu \mathrm{l} \text { of } 3 \times 10^{9} / \mathrm{ml} \\
\text { PFU sprayed onto } \\
\text { debrided wound }\end{array}$ & $\begin{array}{l}\sim 10^{9} \text { vs. } 0 \text { CFU, day } 8 \\
\text { control vs. treatment }\end{array}$ & $\begin{array}{l}\text { Shivaswamy et al., } \\
2015\end{array}$ \\
\hline $\begin{array}{l}\text { Klebsiella } \\
\text { pneumoniae }\end{array}$ & $48,72 \mathrm{~h}$ & $\begin{array}{l}\text { Intranasal } 10^{4} \\
\text { CFU/mouse }\end{array}$ & Lobar pneumonia & $\begin{array}{l}\text { IP, liposome-entrapped } \\
\text { phages }{ }^{i}\end{array}$ & $\begin{array}{l}\sim 10^{5} \text { vs. } \sim 10^{3} \text { vs. } 0 \text { CFU, } \\
\text { day } 5 \text {, control vs. } 72 \text {-h delay } \\
\text { vs. } 48 \text {-h delayj }\end{array}$ & Singla et al., 2015 \\
\hline $\begin{array}{l}\text { Staphylococcus } \\
\text { aureus (MRSA) }\end{array}$ & $\begin{array}{l}504 \\
1008 h^{k}\end{array}$ & $\begin{array}{l}\text { Intramedullary injection } \\
\text { of rabbits with } \\
\text { uncertain number } \\
\left(\leq 5 \times 10^{6}\right) \mathrm{CFU}\end{array}$ & $\begin{array}{l}\text { Chronic } \\
\text { osteomyelitis }\end{array}$ & $\begin{array}{l}\text { Intralesional injection of } \\
5 \times 10^{11} \mathrm{PFU}, 4 \text { doses }\end{array}$ & $\begin{array}{l}\text { Cure of infection versus (for } \\
504 \text { h delay) lack of cure } \\
\text { w/o treatment }\end{array}$ & Kishor et al., 2016 \\
\hline
\end{tabular}

${ }^{a}$ CFU, Colony-Forming Units; IP, Intraperitoneal; IV, Intravenous; MRSA, Methicillin-Resistant or Multi-drug Resistant Staphylococcus aureus; PFU, Plaque-Forming Units.

${ }^{b}$ Time between initial exposure to bacteria and initial exposure to phages. Shown per study are only those delays of longer than $24 \mathrm{~h}$.

${ }^{c}$ Day indicated is post initial bacterial challenge.

${ }^{d}$ It is difficult to tell whether the phage administration was or was not made directly to the abscess.

e Phages were presumably delivered intravenously, though this is not explicitly stated.

${ }^{f}$ Phage additions were either 48- to 96-h prior to (96-h treatment) or 48- to 96-h post (240-h treatment) the cyclophosphamide-mediated induction of septicemia.

9 This was followed days later by cyclophosphamide IP injection to induce septicemia.

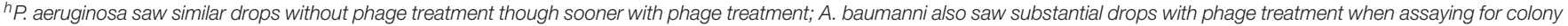
counts using selective media; mostly analogous though not identical and also more variable results were seen for S. aureus and P. aeruginosa with an otherwise equivalent pig model. ${ }^{i} B$ oth free and liposome-entrapped phages were administered in this study representing concentrations of $10^{9}$ and $10^{7}$ PFU/ml and multiplicities of infection of 1 and 0.01 , respectively.

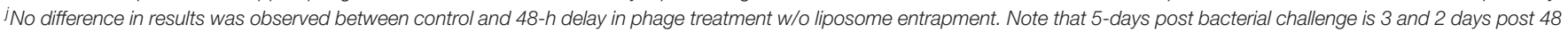

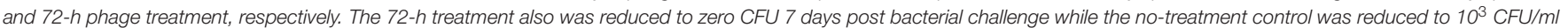
at 7 days.

${ }^{k} 3$ and 6 weeks, respectively, though the 3-week treatment may in fact have actually begun on day 16. 
to "lysis from without" (Abedon, 2011) but which the authors appear to be equating, incorrectly, with the concept of inundation (Payne and Jansen, 2001). Inundation therapy generally is assumed to involve bacteria killing though not necessarily also phage replication nor even bacterial lysis.

A much more substantive concern is that these authors have, in essence, made their reported treatment look too easy. This is not a criticism of the results presented but instead stems from a much more general question of just what constitutes a chronic bacterial infection as typically treated clinically using phage therapy. Thus, does this rabbit osteomyelitis model, impressive as it appears, come close to actually modeling antibiotic-tolerant chronic bacterial infections?

The authors indicate that chronic osteomyelitis is defined by bone inflammation that has lasted for at least 6 weeks. By contrast, by the time phage treatment has begun in the clinic, chronic infections typically have persisted, often despite ongoing antibiotic treatment, for up to many years, e.g., a median of 43 months as reported by Miedzybrodzki et al. (2012). Differences therefore may exist between chronic osteomyelitis at 6 weeks and that which phage therapists may encounter in the clinic, and particularly so given that there have been delays in treatment until after more conventional approaches have failed.

Drawing on the Kishor et al. (2016) study as well as others presented in Table 1, I would like to suggest five criteria for judging experimental animal infections as models for phage therapy of chronic infections as encountered in the clinic. As the first criterion should be assumed as a given, I start the list at zero:

0. Substantial delays, e.g., multiple days, weeks, or longer, following bacterial challenge; minimally including demonstration of some degree of infection stabilization prior to the onset of phage treatment.

1. Equivalent degrees of site preparation as used clinically prior to the onset of treatment, e.g., debridement in the case of wound infections.

Generally these should be followed with at least two of the following:

\section{REFERENCES}

Abedon, S. T. (2011). Lysis from without. Bacteriophage 1, 46-49. doi: 10.4161/bact.1.1.13980

Capparelli, R., Nocerino, N., Iannaccone, M., Ercolini, D., Parlato, M., Chiara, M., et al. (2010). Bacteriophage therapy of Salmonella enterica: a fresh appraisal of bacteriophage therapy. J. Infect. Dis. 201, 52-61. doi: 10.1086/ 648478

Capparelli, R., Parlato, M., Borriello, G., Salvatore, P., and Iannelli, D. (2007). Experimental phage therapy against Staphylococcus aureus in mice. Antimicrob. Agents Chemother. 51, 2765-2773. doi: 10.1128/AAC.01513-06

Chhibber, S., Gupta, P., and Kaur, S. (2014). Bacteriophage as effective decolonising agent for elimination of MRSA from anterior nares of BALB/c mice. BMC Microbiol. 14:212. doi: 10.1186/s12866-014-0212-8

Chibani-Chennoufi, S., Sidoti, J., Bruttin, A., Kutter, E., Sarker, S., and Brüssow, H. (2004). In vitro and in vivo bacteriolytic activities of Escherichia coli phages: implications for phage therapy. Antimicrob. Agents Chemother. 48, 2558-2569. doi: 10.1128/AAC.48.7.2558-2569.2004
2. Demonstration, in most cases, of a lack of adequate treatment success without multiple, temporally separated phage applications over relatively long periods, i.e., if multiple doses over weeks are required in the clinic to adequately combat chronic infections then success using only a single dose in the laboratory ought to be suspect.

3. Demonstration, in many cases, of development of biofilms prior to treatment.

4. Demonstration of physiological development, by model infections, of antibiotic tolerance.

The latter point in a sense is an operational definition since chronic infections can become eligible for phage therapy due to a failure to be effectively treated using antibiotics-failures which are not necessarily consequences of genetically acquired resistance and particularly as associated with biofilm formation. Thus, chronic infection models for phage therapy in at least some cases should be ones for which antibiotics, as normally employed, have lost their ability to clear otherwise laboratory-sensitive bacteria over the course of infection development.

In conclusion, with few quibbles, I want to stress that I am delighted with Kishor et al.'s efforts. But, as with good science generally, as many questions are raised by their study as have been answered.

\section{AUTHOR CONTRIBUTIONS}

The author confirms being the sole contributor of this work and approved it for publication.

\section{ACKNOWLEDGMENTS}

The author has consulted and served on advisory boards for companies with phage therapy interests, holds equity stake in a number of these companies, and maintains the websites phage.org and phage-therapy.org. The text presented, however, represents the perspective of the author alone and no help was received in its writing.

Danelishvili, L., Young, L. S., and Bermudez, L. E. (2006). In vivo efficacy of phage therapy for Mycobacterium avium infection as delivered by a nonvirulent mycobacterium. Microb. Drug Res. 12, 1-6. doi: 10.1089/mdr.2006.12.1

Drilling, A., Morales, S., Boase, S., Jervis-Bardy, J., James, C., Jardeleza, C., et al. (2014). Safety and efficacy of topical bacteriophage and ethylenediaminetetraacetic acid treatment of Staphylococcus aureus infection in a sheep model of sinusitis. Int. Forum Allergy Rhinol. 4, 176-186. doi: 10.1002/alr.21270

Kishor, C., Mishra, R. R., Saraf, S. K., Kumar, M., Srivastav, A. K., and Nath, G. (2016). Phage therapy of staphylococcal chronic osteomyelitis in experimental animal model. Indian J. Med. Res. 143, 87-94. doi: 10.4103/0971-5916.178615

Langdon, A., Crook, N., and Dantas, G. (2016). The effects of antibiotics on the microbiome throughout development and alternative approaches for therapeutic modulation. Genome Med. 8:1. doi: 10.1186/s13073-016-0294-z

Mendes, J. J., Leandro, C., Corte-Real, S., Barbosa, R., Cavaco-Silva, P., MeloCristino, J., et al. (2013). Wound healing potential of topical bacteriophage therapy on diabetic cutaneous wounds. Wound Repair Regen. 21, 595-603. doi: 10.1111/wrr.12056 
Miedzybrodzki, R., Borysowski, J., Weber-Dabrowska, B., Fortuna, W., Letkiewicz, S., Szufnarowski, K., et al. (2012). Clinical aspects of phage therapy. Adv. Virus Res. 83, 73-121. doi: 10.1016/B978-0-12-394438-2.00003-7

Olsen, I. (2015). Biofilm-specific antibiotic tolerance and resistance. Eur. J. Clin. Microbiol. Infect. Dis. 34, 877-886. doi: 10.1007/s10096-015-2323-z

Payne, R. J. H., and Jansen, V. A. A. (2001). Understanding bacteriophage therapy as a density-dependent kinetic process. J. Theor. Biol. 208, 37-48. doi: 10.1006/jtbi.2000.2198

Rhoads, D. D., Wolcott, R. D., Kuskowski, M. A., Wolcott, B. M., Ward, L. S., and Sulakvelidze, A. (2009). Bacteriophage therapy of venous leg ulcers in humans: results of a phase I safety trial. J. Wound Care 18, 237-244. doi: 10.12968/jowc.2009.18.6.42801

Shivaswamy, V. C., Kalasuramath, S. B., Sadanand, C. K., Basavaraju, A. K., Ginnavaram, V., Bille, S., et al. (2015). Ability of bacteriophage in resolving wound infection caused by multidrug-resistant Acinetobacter baumannii in uncontrolled diabetic rats. Microb. Drug Resist. 21, 171-177. doi: 10.1089/mdr.2014.0120

Singla, S., Harjai, K., Katare, O. P., and Chhibber, S. (2015). Bacteriophage-loaded nanostructured lipid carrier: improved pharmacokinetics mediates effective resolution of Klebsiella pneumoniae induced lobar pneumonia. J. Infect. Dis. 212, 325-334. doi: 10.1093/infdis/jiv029

Tanji, Y., Shimada, T., Fukudomi, H., Miyanaga, K., Nakai, Y., and Unno, H. (2005). Therapeutic use of phage cocktail for controlling Escherichia coli O157:H7 in gastrointestinal tract of mice. J. Biosci. Bioeng. 100, 280-287. doi: $10.1263 / \mathrm{jbb} .100 .280$
Trigo, G., Martins, T. G., Fraga, A. G., Longatto-Filho, A., Castro, A. G., Azeredo, J., et al. (2013). Phage therapy is effective against infection by Mycobacterium ulcerans in a murine footpad model. PLoS Negl. Trop. Dis. 7:e2183. doi: 10.1371/journal.pntd.0002183

Watanabe, R., Matsumoto, T., Sano, G., Ishii, Y., Tateda, K., Sumiyama, Y., et al. (2007). Efficacy of bacteriophage therapy against gut-derived sepsis caused by Pseudomonas aeruginosa in mice. Antimicrob. Agents Chemother. 51, 446-452. doi: 10.1128/AAC.00635-06

Wright, A., Hawkins, C. H., Anggård, E. E., and Harper, D. R. (2009). A controlled clinical trial of a therapeutic bacteriophage preparation in chronic otitis due to antibiotic-resistant Pseudomonas aeruginosa; a preliminary report of efficacy. Clin. Otolaryng. 34, 349-357. doi: 10.1111/j.1749-4486.2009. 01973.x

Conflict of Interest Statement: The author declares that the research was conducted in the absence of any commercial or financial relationships that could be construed as a potential conflict of interest.

Copyright (c) 2016 Abedon. This is an open-access article distributed under the terms of the Creative Commons Attribution License (CC BY). The use, distribution or reproduction in other forums is permitted, provided the original author(s) or licensor are credited and that the original publication in this journal is cited, in accordance with accepted academic practice. No use, distribution or reproduction is permitted which does not comply with these terms. 